\title{
Does Inflation Respond to Interest Rates Changes?
}

\author{
Rama Chandra*, Sumitro Sumitro \\ Department Management \\ Sekolah Tinggi Ilmu Ekonomi Indonesia \\ Jakarta, Indonesia \\ *rama_chandra@stei.ac.id, sumitro@stei.ac.id
}

\begin{abstract}
This study aims to analyse the response of inflation to changes in interest rates in Indonesia, thus analysing the interrelations between the two variables. The analysis uses the Granger Causality Test and Impulse Response Function approach to monthly time series data for the period January 2014 to June 2018, which includes Consumer Price Index, SBI Interest Rates, Interbank Money Market Interest Rates and Deposit Interest Rates. There is one-direction causality between the SBSBI and CPI. The government responded to the inflation rate by making SBSI adjustments this indicates the operation of monetary policy. The impact of changes in the inflation rate to SBSI lasted for six months. SBSI Adjustments are transmitted on the money market through deposits and credit. Changes in deposit and credit interest rates were responded to by inflation.
\end{abstract}

Keywords: inflation, interest rates, Granger Causality Test, vector auto regression

\section{INTRODUCTION}

Low and stable inflation is a prerequisite for sustainable economic growth which in turn provides benefits for improving people's welfare. The importance of controlling inflation is based on the consideration that high and unstable inflation has a negative impact on the socio-economic conditions of society. (1) High inflation will cause the real income of the community will continue to fall so that the standard of living of the community will decrease and eventually make all people, especially the poor, poorer. (2) Unstable inflation will create uncertainty for economic actors in making decisions. Empirical experience shows that unstable inflation will complicate people's decisions in consumption, investment and production, which in turn will reduce economic growth. (3) The domestic inflation rate that is higher than the inflation rate in neighbouring countries makes the real domestic interest rate uncompetitive so that it can put pressure on the Rupiah [1].

One of the roles of Bank Indonesia (BI) as the Central Bank in maintaining financial system stability is through the adoption of the Inflation Targeting Framework, abbreviated as ITF. This framework has been formally adopted since July 2005. In ITF the role of monetary policy is carried out through interest rate instruments in open market operations. ITF is expected to be able to create appropriate and balanced monetary policies. Monetary policy through the application of interest rates that are too strict, will tend to be deadly in economic activity, and vice versa.
Within this framework, BI explicitly announces the inflation target to the public and monetary policy is directed towards achieving the inflation target set. Monetary policy is carried out in a forward looking manner, meaning that changes in monetary policy stance are carried out through evaluation of future inflation developments associated with the inflation target that has been declared. In addition, within this framework, monetary policy is also characterized by transparency and accountability of policies to the public. Operationally, the monetary policy stance is reflected by setting the policy interest rate (BI Rate) which is expected to affect money market rates, deposit rates and bank credit rates. This change in interest rates will ultimately affect output and inflation.

\section{THEORETICAL FRAMEWORK}

\section{A. Inflation Targeting Framework}

The ITF is a policy framework for controlling inflation. In Indonesia inflation control is an important policy target for realizing sustainable growth. This is reflected in the Decree of the President of the Republic of Indonesia number 23 of 2017, concerning the formation of the National Inflation Control Team, in order to maintain a low and stable inflation rate, as a prerequisite for sustainable economic growth which ultimately will provide benefits for improving people's welfare. If inflation is not controlled the negative impacts will occur that have broad dimensions in the economy [2]. There are three main activities in the ITF (1) setting inflation targets, (2) conducting inflation projections (3) setting operational policies in achieving inflation targets. Inflation targeting is a forwardlooking monetary policy strategy, so in order to set an inflation target it is necessary to pay attention to the level of inflation that has been occurring so far and long-term inflation [3] and flexibility to achieve this target if shocks occur in the economy [4].

The timeframe for achieving targeted inflation differs for each country depending on the initial inflation. For countries that have a much lower initial inflation, the period for achieving targeted inflation requires a longer time. Debelle recommends a period of around two years for achieving targets for countries that have high initial inflation. This is because it is related to the economic structure. Finland and Sweden, for example, since implementing the inflation targeting regime in 1993, need no less than two years to achieve the inflation target [5]. 
intermediate target. Several operational target options that can be used include short-term interest rates.

This study uses a causality model between variables using the Granger Causality Test which includes reciprocal relationships and functions that emerge from the analysis of variables, especially the full relationship between variables and partial relationships between variables [6]. The Granger approach is used to determine the value of a variable $(\mathrm{Y})$ that can be explained by its past values and whether adding the past value (lag) of a variable $\mathrm{X}$ can increase the ability of the independent variable in explaining $X$. From an econometric view the main ideas of causality are as follows (1) if $\mathrm{X}$ affects $\mathrm{Y}$, it means that the past X can be a predictor of $\mathrm{Y}$. In other words, adding X's past data to Y's regression with Y's past data can increase the explanatory power of the regression. (2) Past $\mathrm{Y}$ data cannot be a predictor of $\mathrm{X}$, because if $\mathrm{X}$ is a predictor of $\mathrm{Y}$ and $\mathrm{Y}$ is a predictor of $\mathrm{X}$, then it is likely that there are other variables, say $\mathrm{Z}$, which affect $\mathrm{X}$ and $\mathrm{Y}$. The causality equation model:

$$
\begin{aligned}
& Y_{t}=\sum_{J=1}^{k} \alpha_{j} Y_{t-j}+\sum_{J=1}^{k} B_{j} X_{t-j}+e_{t} \\
& X_{t}=\sum_{J=1}^{k} \delta_{j} X_{t-j}+\sum_{J=1}^{k} \ell_{j} y_{t-j}+U_{t}
\end{aligned}
$$

In this VAR model it is required that the error terms $e_{t}$ and $\mathrm{U}_{\mathrm{t}}$ have no relationship with each other (white-noise series), while $\mathrm{k}$ is the number of lags. Therefore, before conducting a causality test, all data must be stationary. X affects $\mathrm{Y}$ or the one-way causality relationship from $\mathrm{X}$ to $\mathrm{Y}$ if the coefficient of $B_{j}$ is not equal to zero. The same thing also $Y$ affects $X$ or there is a one-way causality relationship from $\mathrm{Y}$ to $\mathrm{X}$ if the coefficient $\ell_{\mathrm{j}}$ is not equal to zero. But if both occur then it is said there is a reciprocal relationship (feedback relationship) between $\mathrm{X}$ and $\mathrm{Y}$ or there is a two-way causality (bidirectional causality) between $\mathrm{X}$ and $\mathrm{Y}[6]$.

\section{RESULTS}

Monthly time series data was used in our empirical analysis. The data was from January 2014 to June 2018 which includes Consumer Price Index (CPI), SBI Interest Rates (SBSBI), Interbank Money Market Interest Rates (SBPUAB) and Deposit Interest Rates (SBDepo).

Most macroeconomic time-series are non-stationary. The variables tend to show similar increasing or decreasing patterns over time. If the data tested is not stationary then the standard VAR model becomes mis-specified when a causality test is used [6]. To detect the stationarity of all data used in the study, a unit root test was performed using the Phillips Perron (PP) test at the first difference level. Based on the Phillips Perron test results by taking into account the critical value shows CPI, SBSBI, SBDepo stationary at the 1st-Difference level and SBPUAB at the level of significance at $\alpha=1 \%$.
The operational target chosen must have a stable relationship with the intermediate target being controlled by the monetary authority, and information is available earlier than the 
Determination of the number of lags in the VAR (vector auto regression) model is used the Var Lag order Selection Criteria test. In the lag order there are various criteria that can be used to determine the optimal number of lags. Determination of the optimal number of lags in this study used the Akaike Information Criterion - AIC criteria.

TABLE II. LAG OPTIMUM CRITERIA

VAR Lag Order Selection Criteria

Endogenous variables : CPI SBSBI SBDEPO SBPUAB

Exogenous variables : C

Included observations : 51

\begin{tabular}{|l|l|l|l|l|l|l|}
\hline \multicolumn{1}{|c|}{ Lag } & \multicolumn{1}{|c|}{ LogL } & \multicolumn{1}{c|}{ LR } & \multicolumn{1}{c|}{ FPE } & \multicolumn{1}{c|}{ AIC } & HIQ \\
\hline 0 & -271.1464 & NA & 0.570390 & 10.79005 & 10.94157 \\
\hline 1 & -105.1633 & 299.4204 & 0.001595 & 4.908364 & 5.665943 \\
\hline 2 & -91.52011 & 22.47111 & 0.001772 & 5.000789 & 6.364430 & $5.197857^{*}$ \\
\hline 3 & -68.62446 & $34.11901^{*}$ & $0.001395^{*}$ & 4.730371 & 5.521876 & 6.700076 \\
\hline 4 & -55.42373 & 17.60098 & 0.004653 & 4.840146 & 7.415914 & 5.483053 \\
\hline
\end{tabular}

LR: sequential modified LR test statistic (each test at $5 \%$ level) FPE: Final prediction error

\section{A. Granger Causality Test Results}

The results of the Granger Causality test for the interest rate path approach are shown in the following table:

TABLE III. PAIRWISE GRANGER CAUSAlity TEST Result

\begin{tabular}{|l|l|l|l|l|l|}
\hline $\begin{array}{c}\text { Null } \\
\text { Hypothesis }\end{array}$ & Obs & \multicolumn{1}{c|}{$\begin{array}{c}\text { F- } \\
\text { Statistic }\end{array}$} & Prob. & Sig. & Direction \\
\hline $\begin{array}{l}\text { SBSBI does } \\
\text { not Granger } \\
\text { cause CPI }\end{array}$ & 52 & 2.06766 & 0.1179 & $10 \%$ & $\begin{array}{l}\text { One- } \\
\text { Direction }\end{array}$ \\
$\begin{array}{l}\text { CPI does not } \\
\text { Granger } \\
\text { cause SBSBI }\end{array}$ & & 2.45413 & $0.0754^{*}$ & & \\
\hline $\begin{array}{l}\text { SBDEPO } \\
\text { does not }\end{array}$ & 52 & 2.39183 & $0.0810^{*}$ & $10 \%$ & One- \\
$\begin{array}{l}\text { Granger } \\
\text { cause CPI } \\
\text { CPI does not } \\
\text { Granger } \\
\text { cause } \\
\text { SBDEPO }\end{array}$ & & 1.36496 & 0.2656 & & Direction \\
\hline $\begin{array}{l}\text { SBPUAB } \\
\text { does not }\end{array}$ & 52 & 3.88694 & $0.0149^{* *}$ & $5 *$ & \\
$\begin{array}{l}\text { Granger } \\
\text { cause CPI } \\
\text { CPI does not }\end{array}$ & & 0.11426 & 0.9513 & & One- \\
$\begin{array}{l}\text { Granger } \\
\text { cause } \\
\text { SBPUAB }\end{array}$ & & & & & \\
\hline
\end{tabular}

- The interest rate of Bank Indonesia certificates (SBSBI) does not influence Inflation (CPI), so we accept the null hypothesis while CPI significantly influences SBSBI at $\alpha=10 \%$ (prob. 0.0754 ) so we reject the null hypothesis. It is concluded that there is one-direction causality between the CPI variable and the SBSBI and does not apply otherwise.
- Deposit interest rates (SBDepo) statistically significantly influences Inflation (CPI) at the significance level $\alpha=10 \%$ (prob. 0.0810 ) so we reject the null hypothesis, whereas CPI does not statistically significantly influence SBDepo (prob. 0.2656) so we accept the null hypothesis. Thus, it is concluded that there is one-direction causality between the SBDepo and CPI, namely the Deposit interest rate which has an impact on inflation and does not apply otherwise.

- Interbank Money Market interest rates (SBPUAB) has significant influences to Inflation (CPI) at level $\alpha=5 \%$ (prob. 0.0149) so we reject the null hypothesis, whereas CPI does not statistically significantly influence SBPUAB (prob. 0.9513) so we accept the null hypothesis. Thus, it is concluded that there is onedirection causality between the SBPUAB and CPI variables, namely only the Interbank Money Market interest rates have a statistically significant impact on inflation and do not apply otherwise.

\section{B. Impulse Response Analysist}

An impulse response is used to determine the effect of changes in interest rates on inflation. With this approach it can also be known that the duration of the effect has disappeared. 
since the shock of the Deposit interest. The impact of felt for

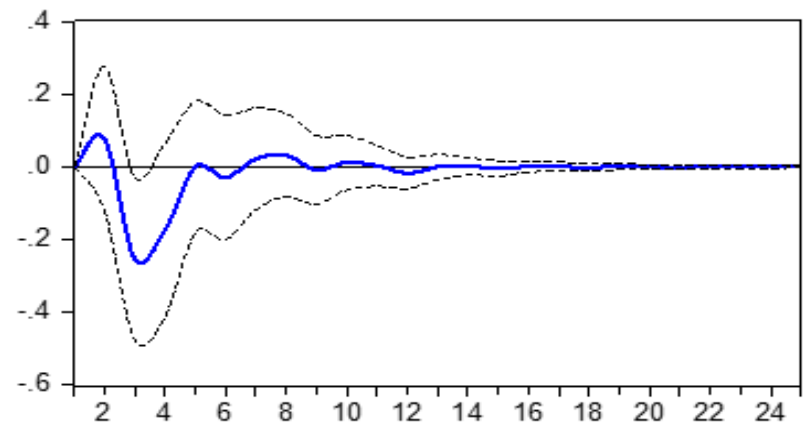

Fig. 1. SBSI impulse response to CPI.

Based on the Pairwise Granger Causality Tests, Bank Indonesia certificate interest rates (SBSBI) responding to changes in inflation (CPI). Figure 1 shows the response of SBSBI to changes in inflation. The government responded to the inflation rate by making SBSI adjustments this indicates the operation of monetary policy. Bank Indonesia is actively adjusting interest rates in a forward looking and pre-emptive manner. The large impact of changes in SBSBI on the inflation rate lasted for six months. Then the effects slowly disappeared until 19 months later.

SBSI Adjustments are transmitted on the money market through deposits and credit. Furthermore, changes in deposit and credit interest rates were responded to by inflation. Figure 2 shows inflation responds to Deposit interest rates (SBDepo).

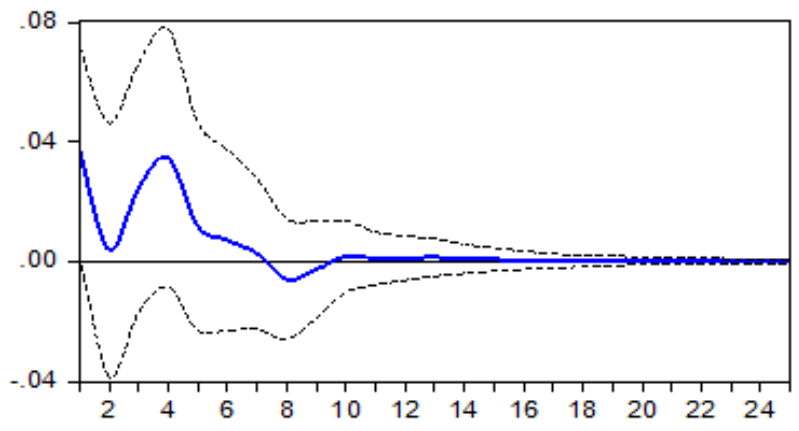

Fig. 2. CPI impulse response to SBDepo.

At the beginning of the period, CPI gave a very fluctuating response above the balance line to negative in the eighth period approximately nine months. Furthermore, after nine months have passed up to the 18th month, the impact of shock began to decrease which is shown by a graph that is not too volatile.

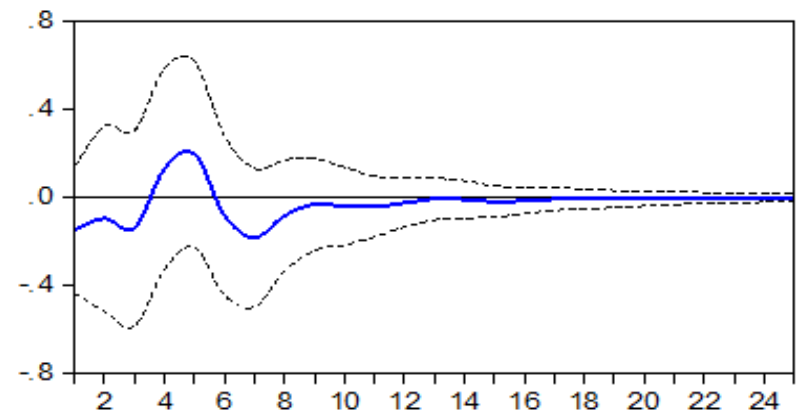

Fig. 3. CPI impulse response to SBPUAB.

At the first to fifth month, the response of CPI to the interbank money market rate fluctuated in the 13th month since the shock.

\section{CONCLUSIONS}

There is one-direction causality between the SBSBI and CPI. The impact of changes in the inflation rate to SBSI lasted for six months. SBSI Adjustments are transmitted on the money market through deposits and credit. Changes in deposit and credit interest rates were responded to by inflation.

\section{REFERENCES}

[1] Bank Indonesia, The Importance of Price Stability, <https://www.bi.go.id/id/moneter/inflasi/pengenalan/Contents/Pentingn ya.aspx $>2018$.

[2] I. Sugema and T. Bakhtiar, "Inflation Targeting in Indonesia: Trade-off and Strategy," European Journal of Economics, Finance and Administrative Sciences, no. 26, 2010.

[3] G. Debelle, Inflation targeting in practice. International Monetary Fund, 1997.

[4] M.G. Lim and G. Debelle, Preliminary considerations of an inflation targeting framework for the Philippines. International Monetary Fund, 1998.

[5] G. Debelle, Inflation targeting in practice. International Monetary Fund, 1997.

[6] P. Kennedy, A guide to econometrics, MIT Press, 2003. 